\title{
Impact of Stock Market, Trade and Bank on Economic Growth for Latin American Countries: An Econometrics Approach
}

\author{
Md. Shakhawat Hossain", Md. Rokonuzzaman \\ Department of Statistics, University of Chittagong, Chittagong, Bangladesh \\ Email address: \\ shakhawat.stat@cu.ac.bd (Md. S. Hossain) \\ ${ }^{*}$ Corresponding author
}

To cite this article:

Md. Shakhawat Hossain, Md. Rokonuzzaman. Impact of Stock Market, Trade and Bank on Economic Growth for Latin American Countries: An Econometrics Approach. Science Journal of Applied Mathematics and Statistics. Vol. 6, No. 1, 2017, pp. 1-6. doi: 10.11648/j.sjams.20180601.11

Received: October 30, 2017; Accepted: November 23, 2017; Published: January 12, 2018

\begin{abstract}
In this study, the impact of stock market, trade and credit by bank on economic growth for nine Latin American countries are examined. Fixed effect panel model with dummy variable approach is used in this research work. Significant Hausman test statistic conferred for fixed effect panel model to analyze this dataset. The inflation rate, import and credit by banking sector have negative impact on GDP growth whereas the rest of the variables, exports, stock market, board money, credit by private sector and interest rate have positive contribution to the GDP growth. Only interest and credit by banking sector are significant. The GDP for Chile is significantly but GDP for all other countries are not significantly different from that of Argentina. In this panel data analysis, $25 \%$ variation of GDP can be explained by the independent variables considered in the model.
\end{abstract}

Keywords: Panel Data, Hausman Test, Fixed Effect Dummy Variable Model, GDP, Stock Market, Trade

\section{Introduction}

Economic growth of a country is mainly determined by the market value, trade and financial sector. It is conventionally measured as the percent rate of increase in real gross domestic product (GDP). Over the past few decades, the world stock markets have surged, and emerging markets have accounted for a large amount of this boom. The speed and extent of stock market development in developing countries have been unprecedented and have lead to fundamental shift both in the financial structures of less developed countries and in the capital flows from developed nations.

Latin America is the sub-region of the Americas comprising those countries where Romance languages are spoken, primarily Spanish and Portuguese. It consists of twenty sovereign states which cover an area that stretches from the southern border of the United Sates to the southern tip of South America, including the Caribbean.

Latin America has economic characteristics that distinguish from other regions of the world, its high level of unequal and that their markets are dominated by monopolies and oligopolies. In such context, it is interesting to analyze the relationship of economic growth with other factors in Latin America.

New theoretical research works show that stock market development might boost economic growth and empirical evidence tends to provide some support to this assertion. Levine and Zervos, for instance, find that stock market development plays an important role in predicting future economic growth [9].

A few number of researches has been conducted research on the relationship between stock market development, banks, trade and economic growth in some countries, also but less organized attempts has been made to study this important financial and economical topic in developing countries and compare the result to have better outcome for making decision in regular basis. Considering the sample countries, nobody studies with Latin American countries in the earlier study as well as in this study more variables are used.

The main purpose of this study is to determine the impact 
of stock market development, trade (export, import) and banks on economic growth in Latin American countries. In this study we use more variables compared to previous studies to examine more credible, applicable, and accurate result by research. Actually we can claim that there has been less study on this topic with these variables.

The rest of the article is organized as follows. In section 2 the literature review, in section 3 data and methodology, in section 4 result and discussion and in the last section summary and conclusion.

\section{Literature Review}

Recently a few number of researchers tried to determine the potential relationship among stock market, banks, trade and economic. Cavenile, Gengenbach and Palm have tried to examine the long term relationship between stock market development and development of banks and economic growth [4]. They used a panel of co-integration methodology to test co-integrating vectors among these three variables for some developing countries. Furthermore, they have tested potential direction of causality between financial development and economic development. Their results indicated to a signal to integrating vector between financial and economic development. It was also concluded that the causality is going from financial development to economic growth.

In some empirical studies, it has been found that countries with higher per capita income are strongly correlated with the use of banking services including access to funding sources fro firms, which, in turn, has positive effects on the real sector. Some of these studies have examined this correlation by suggested by the theory as pointed out by Demirguc-kunt, A. and L. Klapper [5].

In a research, Hossain, et. al showed that market capitalization and domestic credit to private sector have a statistically significant positive contribution to the economic growth (GDP) for SAARC countries [7]. Najid, A. and UmaTul, S. J. found a positive relation between inflation and economic growth of Pakistan [13]. The empirical results of Bayar, Y. and et. al indicated that there is a long run relationship between economic growth and stock market capitalization, total value of stock traded, turnover ratio of stocks traded [2].

Levine and Zervos found that various measures of stock market activity are positively correlated with measures of real economic growth across countries, and that the association is particularly strong for developing countries [10]. Their results also show that after controlling for initial conditions and economic and political factors, the measures of banking and stock market development are robustly correlated with current and future rates of economic growth and productivity improvement.

Calderon-Rossell developed a partial equilibrium model of stock market growth [3]. This model, to date model represents the most comprehensive attempt to develop the foundation of a financial theory of stock market development. Recent works tend to focus on the role of financial liberalization in promoting stock market development.

El-Wassal investigates the relationship between stock market growth and economic growth, financial liberalization, and foreign portfolio investment in 40 emerging markets between 1980 and 2000 [6]. The result shows that economic growth, financial liberalization policies, and foreign portfolio investments were the leading factors of the emerging stock markets growth.

Many other researchers also studied to identify the factors, specially related to financial sectors, affects on the economic growth for different countries or regions [1], [11], [12]. Most of the cases they only used simple statistical tools.

In the next chapter, we will discuss about data and methodology.

\section{Data and Methodology}

In this study, Argentina, Bolivia, Brazil, Chile, Mexico, Paraguay, Peru, Uruguay, Venezuela are considered as sample countries because of the availability of the data for the whole period. Therefore the data are collected based on financial, banking and economical information of these selected countries for the period 1987-2013. All the information is collected from World Bank database. Most important and related eight variables are considered in this study. Specifically, this study examines the impact of inflation, export, import, market capitalization of listed companies, domestic credit to private sector by bank, broad money, real interest rate, domestic credit to financial sector on GDP of sample countries.

The following conceptual model is used in the analysis.

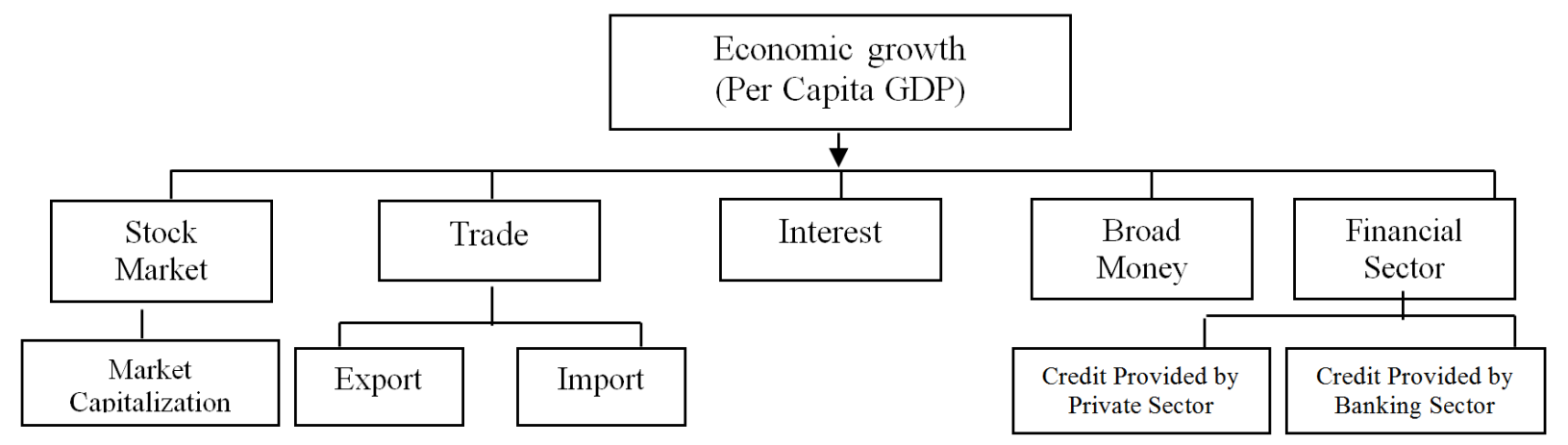

Figure 1. Layout of Conceptual model for this study. 
In this research work, to analyze the data least square dummy variable regression model, panel regression model are used for choosing appropriate model that are describe below;

In this study following variables are considered:

Dependent variable:

Per capita GDP growth in\% (GDP)

Independent variables:

Inflation rate in \% to GDP (Inflation), Exports of goods and services in USD (Exports), Imports of goods and services in USD (Imports), Market capitalization of listed companies in USD (Market), Domestic credit to private sector by bank to GDP in USD (DPS), Broad money to GDP in USD
(Broadmoney), Real interest rate in $\%$ to GDP (Interest), Domestic credit provided by financial sector to GDP in USD (dpf).

In this study, at first various descriptive statistics for all the considered variables are examined. Then fit the models given below using OLS method for the collected dataset. We also compare fixed effect and random effect models. Applying the Hausman test we choose the fixed effect model for our panel data.

Following two regression models are used in different approaches:

Model 1:

$$
\begin{gathered}
G D P=\beta_{0}+\beta_{1}(\text { Inflation })+\beta_{2}(\text { Exports })+\beta_{3}(\text { Imports })+\beta_{4}(\text { Market })+\beta_{5}(d p s)+\beta_{6}(\text { Broadmoney })+ \\
\beta_{7}(\text { Interest })+\beta_{8}(d p f)+\text { Error }
\end{gathered}
$$

Model 2:

$$
\begin{gathered}
G D P=\beta_{0}+\beta_{1}(\text { Inflation })+\beta_{2}(\text { Exports })+\beta_{3}(\text { Imports })+\beta_{4}(\text { Market })+\beta_{5}(\text { dps })+\beta_{6}(\text { Broadmoney })+ \\
\beta_{7}(\text { Interest })+\beta_{8}(\text { dpf })+\alpha_{1}(\text { Bolivia })+\alpha_{2}(\text { Brazil })+\alpha_{3}(\text { Chile })+\alpha_{4}(\text { Mexico })+\alpha_{5}(\text { Paraguay })+\alpha_{6}(\text { Peru })+ \\
\alpha_{7}(\text { Uruguay })+\alpha_{8}(\text { Venezuala })+\text { Error }
\end{gathered}
$$

\section{Results and Discussion}

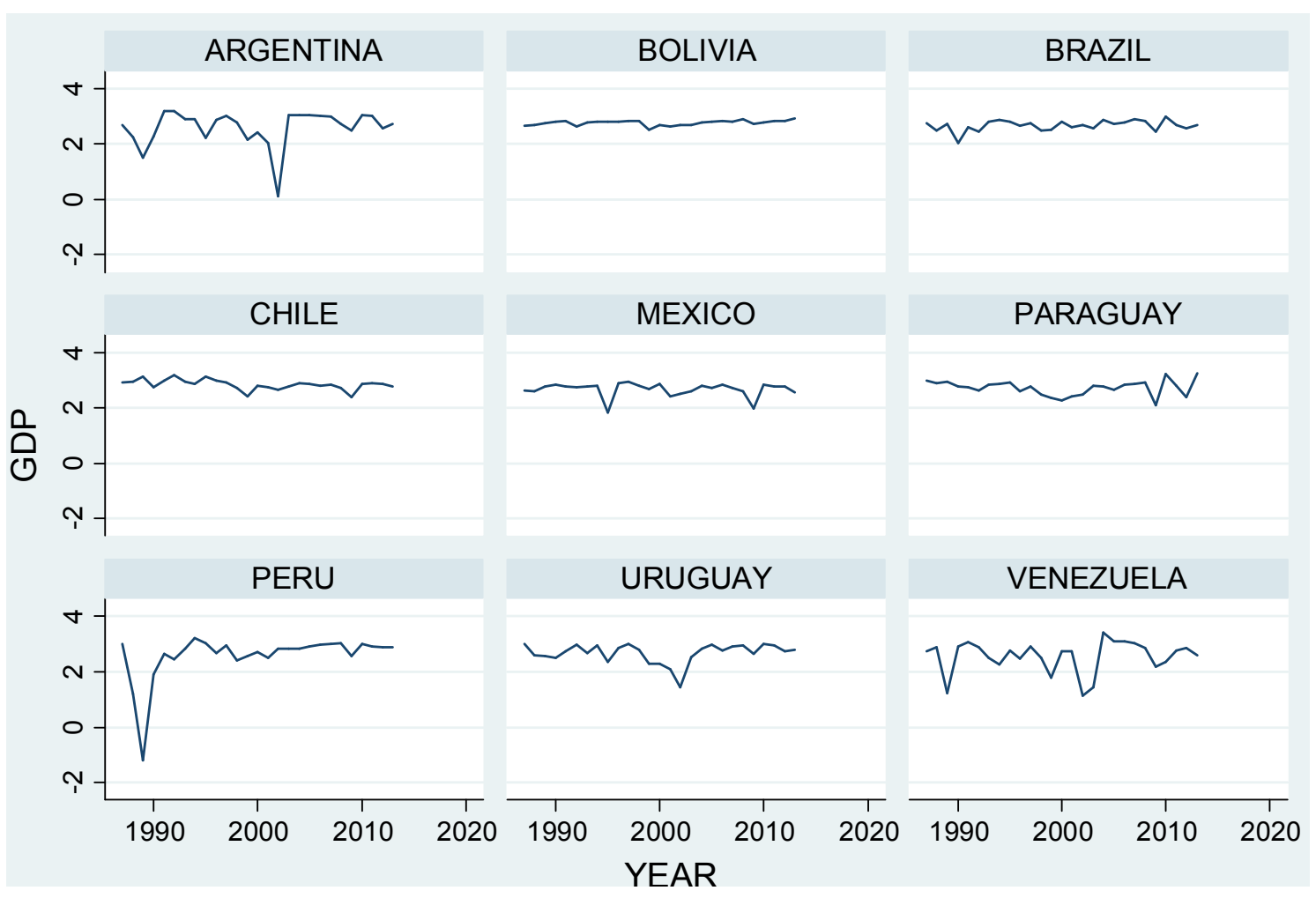

Figure 2. Line diagram of country wise gdp in percentage annual.

The GDP growths for different countries are shown in Figure 2. It is obvious from the figure that the GDP growths for different countries are not similar. There have distinctions of GDP growth from country to country. Also it is seen that GDP line for Bolivia, Brazil, Chile, Mexico and Paraguay are not too much fluctuating but GDP for Argentina, Peru and Venezuela are very much fluctuating.
The descriptive statistics for the different variables that we considered to analyze in the panel regression model are presented in Table 1 and Table 2.

From the Table 1, it is observed that, Brazil has the lowest mean of per capita GDP growth $(2.62 \%)$ while Chile has the highest mean of per capita GDP growth $(5.43 \%)$. From the Table 1 , it is also observed that the mean inflation rates are in 
single digit only for Bolivia and Chile while for other countries mean inflation rates are very high especially in Argentina, Brazil and Peru. Table 1 also shows that exports and imports of Bolivia, Paraguay and Uruguay are very low and the height for the Mexico.

Table 1. Country wise descriptive statistics for annual GDP (\%), inflation (\%), exports and imports.

\begin{tabular}{|c|c|c|c|c|c|c|c|c|}
\hline \multirow{2}{*}{ Country } & \multicolumn{2}{|c|}{ GDP (\%) } & \multicolumn{2}{|c|}{ Inflation (\%) } & \multicolumn{2}{|c|}{ Exports (in billion USD) } & \multicolumn{2}{|c|}{ Imports (in billion USD) } \\
\hline & Mean & SD & Mean & SD & Mean & SD & Mean & SD \\
\hline Argentina & 3.34 & 6.11 & 222.67 & 693.72 & 41 & 28 & 34 & 19 \\
\hline Bolivia & 3.97 & 1.46 & 8.91 & 5.06 & 3.3 & 3.2 & 2.5 & 0.94 \\
\hline Brazil & 2.62 & 2.54 & 395.42 & 769.20 & 110 & 87 & 110 & 64 \\
\hline Chile & 5.43 & 3.00 & 9.02 & 7.33 & 38 & 30 & 31 & 21 \\
\hline Mexico & 2.82 & 2.95 & 21.32 & 31.99 & 170 & 120 & 180 & 100 \\
\hline Paraguay & 3.74 & 4.14 & 13.42 & 9.64 & 6.1 & 3.3 & 3.9 & 1.1 \\
\hline Peru & 3.61 & 5.52 & 366.48 & 1184.1 & 17 & 16 & 15 & 8.9 \\
\hline Uruguay & 3.38 & 4.20 & 29.47 & 31.91 & 5 & 3.2 & 4.9 & 2.4 \\
\hline Venezuela & 2.77 & 6.36 & 35.88 & 23.76 & 41 & 31 & 25 & 16 \\
\hline Overall & 3.52 & 4.34 & 122.51 & 537.97 & 48 & 74 & 44 & 69 \\
\hline
\end{tabular}

* SD for standard deviation.

From Table 2, it is found that average market capitalization is the lowest ( 0.17 billion dollar) for Uruguay and followed by Paraguay ( 0.3 billion dollar) while Brazil has the height average market capitalization (440 billion dollar).

Table 2. Country wise descriptive statistics for market, DCPS, interest and broad money.

\begin{tabular}{|c|c|c|c|c|c|c|c|c|}
\hline \multirow{2}{*}{ Country } & \multicolumn{2}{|c|}{ Market Capitalization (in billion USD) } & \multicolumn{2}{|l|}{ DPS } & \multicolumn{2}{|c|}{ Interest Rate } & \multicolumn{2}{|c|}{ Broad Money } \\
\hline & Mean & SD & Mean & SD & Mean & SD & Mean & SD \\
\hline Argentina & 56 & 43 & 15.51 & 6.072 & 5.45 & 8.90 & 21.71 & 4.50 \\
\hline Bolivia & 1.6 & 1.2 & 40.95 & 13.36 & 19.54 & 14.63 & 49.31 & 16.37 \\
\hline Brazil & 440 & 470 & 52.06 & 29.44 & 46.25 & 12.28 & 56.10 & 20.85 \\
\hline Chile & 110 & 93 & 58.22 & 10.33 & 6.79 & 6.76 & 64.83 & 21.59 \\
\hline Mexico & 200 & 140 & 18.15 & 4.896 & 4.02 & 5.35 & 26.08 & 4.55 \\
\hline Paraguay & 0.3 & 0.22 & 23.15 & 8.84 & 16.63 & 7.03 & 28.98 & 8.03 \\
\hline Peru & 31 & 34 & 19.64 & 7.75 & 16.25 & 26.29 & 29.68 & 7.08 \\
\hline Uruguay & 0.17 & 0.48 & 31.42 & 11.51 & 24.34 & 20.75 & 44.62 & 6.75 \\
\hline Venezuela & 7.4 & 4.6 & 16.87 & 6.727 & -4.44 & 14.89 & 28.86 & 7.74 \\
\hline Overall & 93 & 210 & 30.66 & 19.9 & 14.98 & 20.00 & 38.91 & 18.98 \\
\hline
\end{tabular}

* SD for standard deviation.

From Table 2 further shows that Argentina has the lowest mean percentage $(15.5 \%)$ of domestic credit provided by private sector to GDP and Chile has the height mean percentage (58\%) of domestic credit provided to GDP by private sector. Varying mean interest rate are also observed from Table 2 among different Latin American countries lowest in Mexico (4\%) followed by Venezuela, Argentina and Chile to the height in Brazil (46\%).

After presenting different descriptive statistics, the parameters are estimated using OLS method in Model 1 and Model 2 and both the results are shown in Table 3. It is observed that, in both cases, GDP has a negative relation with inflation rate, imports and domestic credit provided by financial sectors while other explanatory variables have positive effects. Among them only inflation rate, exports, interest rate and domestic credit provided by financial sectors are significant for OLS estimates with Model 1. Similarly for OLS estimates with Model 2 that is dummy variable approach only interest rate and domestic credit provided by financial sectors show significant effect and in addition of that Chile has significant effect on economic growth. Comparing the results of both models it is obvious that regression model with countries as dummy variable (Model 2), that is, a panel model would be preferable.

Table 3. Stata output, comparison between OLS estimates and LSDV estimates.

\begin{tabular}{lll}
\hline Variable & Ols & ols_dum \\
\hline inflation & $-.05682024^{* *}$ & -.00897866 \\
exports & $.15542971^{*}$ & .11213541 \\
imports & -.13897127 & -.0012775 \\
market & .01153284 & .01065404 \\
dps & .10831293 & .02425158 \\
Broadmoney & .0721583 & .06991204 \\
Interest & $.46904692^{* *}$ & $.58518178^{* * *}$ \\
Dpf & $-.20722261^{*}$ & -.29429931 \\
Bolivia & & .42596975 \\
Brazil & & -.09363567 \\
Chile & & $.42269494 * *$ \\
Mexico & & -.04102768 \\
Paraguay & & .1786963 \\
Peru & & -.04556842 \\
Uruguay & & .25298628 \\
Venezuela & & .03730372 \\
cons & .3193829 & -2.0425465 \\
N & 243 & 243 \\
\hline
\end{tabular}

legend: $* \mathrm{p}<0.05 ; * * \mathrm{p}<0.01 ; * * * \mathrm{p}<0.001$. 
In the next step the Hausman test is conducted to test the null hypothesis that a random effect model is appropriate for this panel data. This test result represents in Table 4. It is found that the Hausman test is significant at 5\% level of significance that is the null hypothesis may be rejected which implies that fixed effect model is appropriate for this panel model.

Table 4. Stata output calculation table for Hausman test.

\begin{tabular}{|c|c|c|c|c|}
\hline \multicolumn{5}{|l|}{ Coefficients } \\
\hline & (b) & (B) & (b-B) & sqrt (diag (V_b-V_B)) \\
\hline & Fixed & Random & Difference & S. E. \\
\hline inflation & -.0089787 & -.0568202 & .0478416 & .0211825 \\
\hline exports & .1121354 & .1554297 & -.0432943 & .0681036 \\
\hline imports & -.0012775 & -.1389713 & .1376938 & .1072459 \\
\hline market & .010654 & .0115328 & -.0008788 & .0316685 \\
\hline dps & .0242516 & .1083129 & -.0840614 & .0353784 \\
\hline interest & .5851818 & .4690469 & .1161349 & .0450867 \\
\hline dpf & -.2942993 & -.2072226 & -.0870767 & .0915803 \\
\hline
\end{tabular}

$\mathrm{b}=$ consistent under Ho and Ha; obtained from xtreg

$\mathrm{B}=$ inconsistent under Ha, efficient under Ho; obtained from xtreg

Test: Ho: difference in coefficients not systematic

chi2 $(8)=(b-B)^{\prime}\left[\left(V_{-} b-V_{-} B\right)^{\wedge}(-1)\right](b-B)=18.79$

Prob $>$ chi2 $=0.0160$

(V_b-V_B is not positive definite)

Thus the final model to analyze the panel data, fixed effect dummy variable model (i.e. Model 2) is used with robust standard error as Hausman test conferred and the results are given in Table 5.

Table 5. The final estimates and its standard error by using least square dummy regression model.

\begin{tabular}{llll}
\hline Source & SS & df & MS \\
\hline Model & 14.7684719 & 16 & .923029496 \\
Residual & 34.2275295 & 226 & .151449246 \\
Total & 48.9960014 & 242 & .202462816 \\
\hline
\end{tabular}

Number of obs=243; F (16, 226)=6.09; Prob > F=0.0000; R-squared=0.3014; Adj R-squared=0.2520; Root MSE=.38916

\begin{tabular}{|c|c|c|c|c|c|c|}
\hline \multirow{2}{*}{$\frac{\text { gdp }}{\text { inflation }}$} & \multirow{2}{*}{$\begin{array}{l}\text { Coef. } \\
-.0089787\end{array}$} & \multirow{2}{*}{$\begin{array}{r}\text { Std. Err. } \\
.0301288\end{array}$} & \multirow{2}{*}{$\begin{array}{l}\mathbf{t} \\
-0.30\end{array}$} & \multirow{2}{*}{$\frac{\mathbf{P}>|\mathbf{t}|}{0.766}$} & \multicolumn{2}{|c|}{ [95\% Conf. Interval] } \\
\hline & & & & & -.0683479 & .0503906 \\
\hline exports & .1121354 & .1023459 & 1.10 & 0.274 & -.0895389 & .3138097 \\
\hline market & .010654 & .0373722 & 0.29 & 0.776 & -.0629885 & .0842965 \\
\hline dps & .0242516 & .1062104 & 0.23 & 0.820 & -.1850377 & .2335409 \\
\hline broadmoney & .069912 & .163117 & 0.43 & 0.669 & -.2515126 & .3913367 \\
\hline interest & .5851818 & .09143 & 6.40 & 0.000 & .4050175 & .7653461 \\
\hline $\mathrm{dpf}$ & -.2942993 & .1268237 & -2.32 & 0.021 & -.5442074 & -.0443912 \\
\hline Bolivia & .4259698 & .2814434 & 1.51 & 0.132 & -.128619 & .9805585 \\
\hline Brazil & -.0936357 & .1899968 & -0.49 & 0.623 & -.4680274 & .2807561 \\
\hline Chile & .4226949 & .1622922 & 2.60 & 0.010 & .1028955 & .7424944 \\
\hline Mexico & -.0410277 & .1626916 & -0.25 & 0.801 & -.3616142 & .2795588 \\
\hline Paraguay & .1786963 & .2771004 & 0.64 & 0.520 & -.3673345 & .7247271 \\
\hline Uruguay & .2529863 & .2738256 & 0.92 & 0.357 & -.2865914 & .792564 \\
\hline Venezuela & .0373037 & .1467696 & 0.25 & 0.800 & -.2519081 & .3265156 \\
\hline cons & -2.042547 & 1.926966 & -1.06 & 0.290 & -5.839665 & 1.754572 \\
\hline
\end{tabular}

From the output in Table 5 we see that inflation rate, imports and domestic credit provided by financial sectors have negative impact on the GDP growth whereas the rest of the explanatory variables have positive contribution to the GDP growth. Only interest rate and domestic credit provided by financial sectors are statistically significant at $5 \%$ level in the model. The GDP for Chile is significantly differing from the GDP of Argentina but GDP for all other countries are not significantly different from the GDP of Argentina. For overall model the F value with $(16,226)$ df is 6.09 which is significant at $1 \%$ level. Furthermore the adjusted $\mathrm{R}^{2}$ is 0.2520 , which is little bit higher than other methods of estimation, implies that $25 \%$ variation of GDP for this panel dataset can be explained by the considered explanatory variables. 


\section{Conclusion}

The paper makes a modest contribution on the role of selected explanatory variables on economic growth in sampled countries. In this study it is found that, Brazil has the lowest mean GDP and Chile has the highest mean GDP. In OLS estimates we observed that, inflation rate, imports, and domestic credit provided by financial sectors have negative effect on GDP growth. On the other hand, rest of the explanatory variables has positive impact on GDP. Inflation, export, interest and domestic credit provided by financial sectors are significant. The value of adjusted R-square is $22.33 \%$ implies that only $22.33 \%$ variation of GDP can be explain by inflation, export, import, market, interest, broad money, domestic credit to financial sector and domestic credit to private sector by bank.

Significant Hausman test statistic conferred for fixed effect panel model to analyze this data. In fixed effect panel model with dummy variable approach, inflation rate, imports and domestic credit provided by financial sectors also have negative impact on GDP growth whereas the rest of the variables have positive contribution to the GDP growth. Only interest rate and domestic credit provided by financial sectors are statistically significant in the model. The GDP for Chile is significantly differ from the GDP of Argentina but GDP for all other countries are not significantly different from the g GDP of Argentina. For overall model the $\mathrm{F}$ value with $(16,226) \mathrm{df}$ is 6.09 which is significant at $1 \%$ level. Furthermore the adjusted $\mathrm{R}^{2}$ is 0.2520 , which is little bit higher than other methods of estimation, implies that $25 \%$ variation of GDP for this panel dataset can be explained by the considered explanatory variables. The findings are consistent with existing theoretical framework as illustrated by several authors.

In case of high inflation rate that is $9 \%$ or above in the sampled countries show a negative and significant impact on the economic growth that are also consistent with the study of Iqbal and Nawaz [8]. So high inflation rate can cause damage to the economy and need to inflation rate low at single digit.

Due to lack of data availability, all of the Latin American countries are not considered in the analysis. One can try to collect the data for all others countries from other sources rather than World Bank database. The study may have model specification errors. More intensive analysis and test procedure can be employed in further research on the same area.

\section{References}

[1] Abbas, A. O. et. al (2016). Impact of Stock Market on Economic Growth Evidence: Dar-es Salam Stock Exchange, Tanzania. Journal of Finance and Accounting, 4 (6), 321-327.

[2] Bayar, Y. and et. al (2014). Effects of Stock Market Development on Economic Growth: Evidence from Turkey. International Journal of Financial Research, 5 (1), 93-100.

[3] Calderon-Rossell, R. (1991). The Determinants of Stock market Growth. In S. G. Rhee and R. P. Chang (Eds.), Pacific Basin Capital Markets Research Proceeding of the Second Annual Pacific Basin Finance Conference, 2, 4-6 June, Bangkok, Thailand.

[4] Cavenile, L., Gengenbach, C., \& Palm, F. (2011). Stock Markets, banks, and long run economic growth: A panel cointegration-based analysis. Research Center on Public and Population Economics (Crepp). 2, 3-46.

[5] Demirguc-Kunt, A., and L. Klapper. (2012). Measuring Financial Inclusion: The Global Findex Database.\| Policy Research Working Paper 6025, World Bank, Washington, DC.

[6] El-Wassal, K. A. (2005). Understanding the Growth in merging Stock Markets. Journal of Emerging Market Finance, 4 (3), $227-61$.

[7] Hossain, M. S. and et. al (2012). The Impact of Stock Market Development and Banks on Economic Growth for SAARC Countries: A Panel Analysis. Asian Journal of Research in Business Economics \& Management, 2 (9), 109-115 (Print).

[8] Iqbal, N., and Nawaz, S. (2010). Investment, Inflation and Economic Growth Nexus. PIDE, 19.

[9] Levine, R. and Zervos, S. (1996). Stock Market Development and Long-run Economic Growth. World Bank Policy Research Paper, 582, 1-27.

[10] Levine, R. and Zervos, S. (1998). Stock Markets, Banks, and Economic Growth. The American Economic Review, 88 (3), 537-558.

[11] Mishal, Z. A. (2011). Financial Development and Economic Growth: Evidence from Jordan Economy. Journal of Business and Economic Studies, 17 (2), 20-35.

[12] Mazumder, M. A. (2015). Stock Market and Economic Development in Bangladesh: A Case Study of Chittagong Stock Exchange. Global Journal of Management and Business Research: C Finance, 15 (2), Ver-1.0, 44-54.

[13] Najid, A. and Uma-Tul, S. J. (2012). The Relationship between Inflation and Economic Growth in Pakistan: An Econometrics Approach. Asian Journal of Research in Business, Economics and Management, 2 (9). 